\title{
Polysulfide dynamics in a marine euxinic environment (Rogoznica Lake, Croatia); importance of anoxygenic photosynthesis
}

SARAH MATEŠA, MILAN ČANKOVIĆ, SUZANA ŠEGOTA AND IRENA CIGLENEČKI-JUŠIĆ

Ruđer Bošković Institute

Presenting Author: smatesa@irb.hr

Rogoznica Lake (RL) is an eutrophic and affected by climate change marine lake on the eastern Adriatic coast $\left(43^{\circ} 32^{\prime} \mathrm{N}\right.$, $\left.15^{\circ} 58^{\prime} \mathrm{E}\right)$. During the year the lake is strongly stratified into oxic and anoxic layers. Due to intense sulfate reduction, anoxic bottom layer is enriched in dissolved $\mathrm{HS}^{-}$(up to $5 \mathrm{mM}$ ). At the oxia-anoxia boundary, a pinkish colored chemocline (up to 50 $\mathrm{cm}$ ) develops seasonally, and it is characterized by a dense population of purple phototrophic sulfur bacteria (PSB) [1]. PSB are known to store sulfur $\mathrm{S}(0)$ intracellularly, which by cell lysis would be released in water, and under euxinic conditions solubilized by $\mathrm{HS}^{-}$in nucleophilic polysulfides, $\mathrm{S}_{\mathrm{X}}{ }^{2-} . \mathrm{S}_{\mathrm{X}}{ }^{2-}$ can play an important role in metal, carbon and sulfur cycles.

In this work, for the first time, differential pulse voltammetry (DPV) was used for direct determination of $\mathrm{S}_{\mathrm{X}}{ }^{2-}$ in euxinic marine environment (RL), where total RSS (mainly $\mathrm{HS}^{-}$) varied between 0.1 and $3 \mathrm{mM}$. Concentration of $\mathrm{S}_{\mathrm{X}}{ }^{2-}$, as well as total RSS, varied seasonally depending on the chemocline position, light intensity and $\mathrm{HS}^{-}$concentration. During stratification in summer, when PSB reached maximum abundance, the presence of $\mathrm{S}_{\mathrm{X}}{ }^{2-}$ was determined in the highest concentrations (up to 0.1 $\mathrm{mM} \mathrm{S}(0)$ ). Maximum was found approx. $1 \mathrm{~m}$ bellow the chemocline, where due to sinking of lysed PSB cells, maximum concentration of biologcally $\mathrm{S}(0)$ would be expected.

Presence of $S(0)$ granules in the cells and their release into water upon cell lysses, induced in laboratory conditions by acidification of the studied sample, was confirmed by AFM. The acidification as a standard methodological step in electroanalytical determination of volatile and nonvolatile RSS $\left(\mathrm{RSS}_{\mathrm{NV}}\right)$ [2] are now proved to overestimate $\mathrm{RSS}_{\mathrm{NV}}$ for $30-50 \%$ in samples enriched in PSB. Results from this study clearly prove the $\mathrm{S}_{\mathrm{X}}{ }^{2-}$ presence in the anoxic water of $\mathrm{RL}$ and shed light on a crutial role of the PSB in their formation and dynamics.

This work was funded by MARRES 1717 project.

[1] M. Čanković, J. Žučko, I. Dupčić Radić, I. Janeković, I.Petrić, I. Ciglenečki, G.Collins, Syst Appl Microbiol, 2019.

[2] E. Bura-Nakić, G.R. Helz, I. Ciglenečki, B. Ćosović, Geochim Cosmochim Acta, 2009. 